\title{
PENGGUNAAN REALISTIC MATHEMATIC EDUCATION DALAM PEMBELAJARAN MATEMATIKA DI SEKOLAH DASAR
}

\author{
Mukti Sintawati ${ }^{1}$, Annisa Utami ${ }^{2}$, Vidara Esa Panuntun ${ }^{3}$ \\ ${ }^{1,2}$ Universitas Ahmad Dahlan, ${ }^{3}$ SD Muhammadiyah Serut Bantul \\ ${ }^{1}$ mukti.sintawati@pgsd.uad.ac.id
}

\begin{abstract}
The low mathematics learning outcomes of students at national and international levels is one of the problems of education in Indonesia. Many factors affect mathematics learning outcomes. Some factors include the use of strategies or learning approaches that are not appropriate in learning mathematics. Abstract mathematical concepts will be difficult for students to accept if the approach used by the teacher does not bridge the thinking concepts of elementary school students whose level of thinking is still at a concrete operational stage. The mismatch of this learning approach causes low interest in learning mathematics so that the impact on student learning outcomes is low too. Therefore teachers must pay attention to the level of thinking of students in choosing the right approach in learning mathematics. One approach that can be used in learning mathematics is Real Mathematics Education (RME). This study aims to determine the effectiveness of RME in terms of interest and learning outcomes in mathematics. This research is a quasi experimental design research. The study population was all grade IV students at SD Muhammadiyah Serut with a total of 32 control classes and 31 experimental classes. Data analysis used was the dependent $t$ test and the independent $t$ test. The results of this study indicate that mathematics learning using $R M E$ is effective in terms of interest in learning and mathematics learning outcomes. The results of this study also indicate learning using RME is more effective than conventional learning in terms of interest in learning mathematics.
\end{abstract}

Keywords: interest; learning outcomes; mathematics; RME

\begin{abstract}
Abstrak
Rendahnya hasil belajar matematika peserta didik di tingkat nasional maupun internasional menjadi salah satu masalah pendidikan di Indonesia. Rendahnya hasil belajar ini disebabkan oleh berbagai faktor. Beberapa faktor diantaranya adalah penggunaan strategi atau pendekatan pembelajaran yang tidak tepat dalam pembelajaran matematika. Konsep matematika yang abstrak akan sulit diterima oleh siswa jika pendekatan yang digunakan guru tidak menjembatani konsep berpikir peserta didik sekolah dasar yang taraf berpikirnya masih pada tahap operasional konkrit. Ketidaksesuaian pendekatan pembelajaran ini menyebabkan minat belajar matematika rendah sehingga berdampak pada hasil belajar peserta didik yang rendah juga. Oleh karena itu guru harus memperhatikan taraf berpikir siswa dalam memilih pendekatan yang tepat dalam pembelajaran matematika. Salah satu pendekatan yang dapat digunakan dalam pembelajaran matematika adalah Realistic Mathematics Education (RME). Penelitian ini bertujuan untuk mengetahui keefektifan RME ditinjau dari minat dan hasil belajar matematika. Penelitian ini merupakan penelitian quasi experimental design. Populasi penelitian seluruh peserta didik kelas IV di SD Muhammadiyah Serut. Teknik pengambilan sampel menggunakan Sampling Jenuh. Pengambilan sampel dilakukan secara acak dengan mengundi kelas IV A dan IVB sebagai kelas eksperimen dan kelas kontrol. Analisis data yang digunakan adalah uji dependent t test dan uji independent $t$ test. Hasil penelitian ini menunjukan bahwa pembelajaran matematika menggunakan RME efektif ditinjau dari minat belajar dan hasil belajar matematika. Hasil penelitian ini juga menunjukkan pembelajaran menggunakan RME lebih efektif dibandingkan pembelajaran konvensional ditinjau dari minat belajar matematika.
\end{abstract}

Kata Kunci: hasil belajar; matematika; minat; RME

\begin{tabular}{llll}
\hline Received & $: 2019-12-24$ & Approved & $: 2020-01-10$ \\
Reviesed & $: 2020-01-04$ & Published & $: 2020-07-31$ \\
\hline
\end{tabular}

Jurnal Cakrawala Pendas is licensed under a Creative Commons AttributionShareAlike 4.0 International License. 


\section{Pendahuluan}

Matematika merupakan salah satu ilmu pengetahuan dasar yang bermanfaat bagi kehidupan sehari-hari. Hudojo (2005) berpendapat bahwa matematika diperlukan dalam kehidupan sehari-hari untuk menghadapi perkembangan ilmu pengetahuan dan teknologi. Pendapat ini sejalan dengan NCTM (2000) yang menyebutkan bahwa kemampuan memahami dan menggunakan matematika akan terus digunakan dalam kehidupan sehari-hari dan di dunia kerja. Oleh karena itu pembelajaran matematika wajib diberikan di sekolah mulai dari sekolah dasar hingga sekolah menengah. Tujuan pembelajaran matematika dalam kurikulum 2013 adalah meningkatkan kemampuan intelektual, membentuk kemampuan peserta didik dalam menyelesaikan suatu masalah, mengkomunikasikan ide-ide, dan mengembangkan karakter peserta didik.

Pentingnya penguasaan matematika bagi peserta didik juga diakui secara internasional. Hal ini terbukti dari adanya beberapa organisasi tingkat dunia yang mengukur kemampuan matematika peserta didik. Salah satu organisasi tingkat dunia yang mengukur kemampuan matematika peserta didik adalah The International Association for the Evaluation of Educational Achievement (IEA). IEA melakukan penilaian kemampuan matematika dan sains peserta didik kelas IV dan kelas VIII diberbagai negara melalui program Trends in International Mathematics and Science Study (TIMSS). Penilaian ini menjadi indikator tentang hasil belajar matematika peserta didik Indonesia dibandingkan peserta didik di negara lain. Namun, hasil TIMSS tahun 2015 menunjukkan bahwa pengetahuan matematika peserta didik di Indonesia masih tertinggal dibandingkan dengan negara-negara lain. Indonesia meraih peringkat 44 dari 49 negara (Mullis dkk, 2015). Rata-rata yang diraih peserta didik di Indonesia adalah 397 sedangkan rata-rata secara keseluruhan adalah 500 .

Hasil belajar matematika peserta didik di Indonesia secara nasional juga belum memuaskan. Daerah Istimewa Yogyakarta yang dikenal sebagai kota pelajar juga masih mempunyai permasalahan pendidikan di bidang matematika. Hal ini dibuktikan dari hasil ujian sekolah tahun 2017 pada mata pelajaran matematika di kota Yogyakarta hanya meraih ratarata 63,65. Hasil ini juga dialami di kabupaten Bantul yang merupakan salah satu kabupaten di DIY. Hasil ini tentu masih jauh dari yang diharapkan dan masih perlu ditingkatkan.

Rendahnya hasil belajar matematika peserta didik pada mata pelajaran matematika di tingkat internasional maupun nasional disebabkan berbagai faktor. Konsep matematika yang abstrak menjadi salah satu faktor tersendiri dalam pembelajaran matematika, sedangkan taraf berpikir peserta didik sekolah dasar masih berada pada tahap konkrit dan operasional konkrit. Berkaitan dengan konsep matematika yang bersifat abstrak, seharusnya guru menyampaikan materi matematika dengan pendekatan yang lebih konkrit. Namun masih ada guru dibeberapa sekolah dasar di kabupaten bantul yang belum menggunakan pendekatan yang konkrit dalam menyampaikan materi matematika. Salah satu SD tersebut adalah SD Muhammadiyah Serut Bantul. Rata-rata nilai ujian sekolah matematika pada tahun 2017 adalah 68,85. Rata-rata tersebut lebih tinggi dibandingkan rata-rata kabupaten namun masih perlu ditingkatkan. Berdasarkan hasil observasi pembelajaran yang dilakukan di SD tersebut, guru belum menggunakan pendekatan yang konkrit secara maksimal karena pengetahuan guru yang masih kurang. Proses pembelajaran yang seperti inilah yang diduga menyebabkan siswa tidak tertarik mengikuti proses pembelajaran matematika sehingga berakibat kurang maksimalnya hasil belajar peserta didik. Ketidaktertarikan peserta didik ini merupakan salah satu indikator rendahnya minat peserta didik dalam mempelajari matematika.

Minat belajar adalah proses motivasi yang kuat yang memberi energi pembelajaran, membimbing lintasan akademik dan karier, dan sangat penting untuk keberhasilan akademik 
(Harackiewicz, Smith, \& Priniski, 2016). Pendapat tersebut menjelaskan bahwa minat mempunyai peranan penting dalam keberhasilan belajar peserta didik. Minat juga dapat diartikan sebagai ketertarikan terhadap objek tertentu sehingga seseorang dapat memberikan perhatiannya terhadap obyek tersebut (Elliot,dkk. 2000). Slameto (2010:180) berteori bahwa minat belajar adalah perasaan suka/senang, ketertarikan, keterlibatan serta memberikan perhatian yang besar dalam belajar. Dari berbagai teori tersebut dapat disimpulkan bahwa minat belajar adalah perasaan suka dan ketertarikan peserta didik terhadap materi tertentu sehingga peserta didik memberikan perhatian dan terlibat dalam pembelajaran.

Keberadaan minat belajar penting dalam pembelajaran. Peserta didik yang minat belajarnya rendah akan berdampak pada rendahnya hasil belajar (Tella, 2007). Pentingnya minat belajar dalam pembelajaran matematika harus menjadi salah satu yang harus diperhatikan guru. Terdapat banyak pendekatan yang diduga dapat digunakan guru dalam meningkatkan minat belajar matematika peserta didik. Pendekatan yang dapat digunakan oleh guru dalam pembelajaran matematika salah satunya adalah pendekatan Realistic Mathematics Education (RME).

RME merupakan pendekatan yang bertujuan untuk membantu peserta didik dalam mempelajari matematika yang bersifat abstrak (Bray \& Tangney, 2015). Pembelajaran RME menggunakan daily life atau contoh kehidupan sehari-hari yang ada disekitar siswa untuk mengenalkan konsep matematika. Menurut Kurino (2019) pembelajaran RME menggunakan konteks permasalahan realistik yang menjadi titik awal pembelajaran serta penggunaan model untuk menjembatani dunia matematika.

Terdapat 2 aspek pembelajaran dalam RME, yaitu matematika horisontal dan matematika vertikal (Heuvel \& Panhuizen, 2003). Lebih lanjut Heuvel \& Panhuizen menjelaskan matematika horisontal merupakan transformasi masalah sehari-hari kedalam simbol matematika. Sedangkan matematika vertikal merupakan mengorganisasikan simbolsimbol matematika untuk menyelesaikan masalah. Clements \& Sarama (2013) menyebutkan bahwa karakteristik utama RME adalah transformasi masalah kontekstual menjadi matematika formal, siswa membuat konsep matematika sendiri, interaksi peserta didik dan guru, dan persepsi matematika sebagai subyek yang terintegrasi. Penggunaan RME yang menggunakan masalah sehari-hari untuk mengenalkan konsep matematika yang abstrak inilah yang dapat meningkatkan ketertaikan dan pemahaman siswa pada pembelajaran matematika. Hal ini didukung hasil penelitian yang dilakukan oleh Laurens et al (2017), pembelajaran menggunakan RME memberikan kontribusi untuk meningkatkan motivasi, percaya diri, kemampuan memecahkan masalah dan penalaran yang berdampak pada peningkatan hasil belajar kognitif siswa.

Keberhasilan RME berdasarkan teori dan penelitian yang telah disebutkan digunakan sebagai dasar penelitian ini untuk melihat keefektifan RME ditinjau dari minat dan hasil belajar matematika peserta didik di SD Muhammadiyah serut.

\section{Metode Penelitian}

Penelitian ini merupakan penelitian quasi experiment dengan nonequivalent (pretest-posttestt) control grup design. Tujuan dari penelitian ini adalah untuk melihat keefektifan RME terhadap minat belajar dan prestasi matematika siswa sekolah dasar. Penelitian menggunakan dua kelas penelitian, yaitu kelompok eksperimen dan kelompok kontrol. Kelompok eksperimen diberi perlakuan pembelajaran matematika menggunakan RME, sedangkan kelompok kontrol dengan pembelajaran konvensional. 
Lokasi penelitian dilaksanakan di SD Muhammadiyah Serut Bantul. Penelitian ini dilaksanakan pada 18 Juli 2019 sampai 25 Juli 2019. Kegiatan penelitian dilakukan 5 kali pertemuan untuk masing-masing kelas. Populasi dari penelitian ini yaitu peserta didik kelas IV SD Muhammadiyah Serut dengan jumlah keseluruhan kelas IVA 32 dan IVB 31. Teknik pengambilan sampel menggunakan Sampling Jenuh karena sampel yang digunakan adalah seluruh populasi siswa kelas IV SD Muhammadiyah Serut Bantul. Pengambilan sampel dilakukan secara acak dengan mengundi kelas IV A dan IVB sebagai kelas eksperimen dan kelas kontrol. Dari hasil undian diperoleh kelas IV A sebagai kelas kontrol dan kelas IV B sebagai kelas eksperimen.

Tahap pelaksanaan kegiatan penelitian ini yaitu tahap membuat instrumen penelitian, validasi instrumen, uji coba instrumen, pretest, perlakuan dan, posttest untuk mengumpulkan data baik pada kelompok eksperimen maupun kelompok kontrol. Teknik pengumpulan data menggunakan tes tertulis dan non tes berupa angket. Instrumen penelitian berupa soal pretest dan posttest prestasi belajar matematika serta angket minat belajar matematika yang telah dinyatakan valid dan reliabel.

Teknik analisis data yang digunakan adalah statistika parametrik. Untuk menguji keefektifan pembelajaran matematika menggunakan RME dan pembelajaran konvensional digunakan uji paired sample $t$ test. Sedangkan untuk membandingkan pembelajaran mana yang lebih efektif menggunakan uji independent sample t-test.

\section{Hasil dan Pembahasan}

Data hasil minat belajar sebelum dan sesudah perlakuan pada kelompok dengan pembelajaran RME dan konvensional dideskripsikan dalam Tabel 1.

Tabel 1

Deskripsi data hasil minat belajar sebelum dan sesudah perlakuan

\begin{tabular}{ccccc}
\hline Nilai & \multicolumn{2}{c}{ Kelas Konvensional } & \multicolumn{2}{c}{ RME } \\
\cline { 2 - 5 } & sebelum & sesudah & Sebelum & sesudah \\
\hline Rata-rata & 7,81 & 10,59 & 8,22 & 12,45 \\
Standar deviasi & 9,418 & 1,738 & 10,029 & 2,110 \\
Nilai maksimum ideal & 20 & 20 & 20 & 20 \\
Nilai minimum ideal & 0 & 0 & 0 & 0 \\
Nilai maksimum & 11 & 15 & 11 & 16 \\
empiris & & 6 & 5 & 9 \\
Nilai minimum empiris & 4 & &
\end{tabular}

Berdasarkan Tabel 1 dapat diketahui bahwa rata-rata minat belajar matematika siswa sebelum dan sesudah perlakuan pada kelas RME lebih tinggi dibandingkan kelas konvensional. Gain rata-rata kelas RME adalah 4,23 sedangkan kelas konvensional adalah 2,78, sehinga peningkatan rata-rata minat belajar kelas RME lebih tinggi dari kelas konvensional. Dari hasil tes minat belajar matematika selanjutnya dikonversi ke dalam kategori tinggi, sedang, dan rendah. Distribusi frekuensi dan persentase minat belajar matematika peserta didik sebelum dan sesudah perlakuan disajikan dalam Tabel 2. 
Tabel 2

Distribusi frekuensi dan persentase minat belajar matematika

\begin{tabular}{ccccccccc}
\hline Kategori & \multicolumn{3}{c}{ Kelas Konvensional } & \multicolumn{3}{c}{ Kelas RME } \\
\cline { 2 - 9 } & \multicolumn{2}{c}{ sebelum } & \multicolumn{2}{c}{ sesudah } & \multicolumn{2}{c}{ Sebelum } & \multicolumn{2}{c}{ Sesudah } \\
\cline { 2 - 9 } & F & $\mathbf{0}$ & F & $\mathbf{0}$ & F & \% & F & \% \\
\hline Tinggi & 0 & 0 & 0 & 0 & 0 & 0 & 2 & 6 \\
Sedang & 0 & 0 & 9 & 28 & 0 & 0 & 17 & 55 \\
Rendah & 32 & 100 & 23 & 72 & 31 & 100 & 12 & 39 \\
\hline
\end{tabular}

Berdasarkan Tabel 2 dapat diketahui bahwa minat belajar matematika peserta didik sebelum diberikan perlakuan tidak ada yang berada pada kategori tinggi dan sedang di kedua kelas. Setelah diberikan perlakuan, ada peningkatan minat belajar matematika peserta didik di kedua kelas. Di kelas RME, terdapat peserta didik yang minat belajarnya berada pada kategori sedang dan tinggi, sedangkan di kelas konvensional hanya kategori sedang.

Rata-rata minat belajar peserta didik berdasarkan aspek-aspek minat belajar matematika disajikan pada Tabel 3.

Tabel 3

Deskripsi data hasil minat belajar sebelum dan sesudah perlakuan

\begin{tabular}{ccccc}
\hline \multirow{2}{*}{ Aspek } & \multicolumn{2}{c}{ Kelas Konvensional } & \multicolumn{2}{c}{ Kelas RME } \\
\cline { 2 - 5 } & sebelum & sesudah & Sebelum & Sesudah \\
\hline Perasaan & 7,92 & 10,32 & 7,99 & 12,45 \\
Perhatian & 7,71 & 10,62 & 8,24 & 12,47 \\
Keterlibatan & 7,66 & 10,71 & 8,52 & 12,53 \\
Ketertarikan & 7,95 & 10,52 & 8,11 & 12,43 \\
\hline
\end{tabular}

Berdasarkan Tabel 3 diketahui bahwa aspek perasaan dan ketertarikan merupakan aspek yang memperoleh skor rata-rata terendah di kedua kelas baik sebelum maupun setelah perlakuan. Sedangkan aspek keterlibatan merupakan aspek yang memperoleh rata-rata teritinggi. Data hasil belajar pada kelompok RME dan pembelajaran konvensional dideskripsikan berdasarkan nilai pretest dan posttest yang disajikan pada Tabel 4.

Tabel 4

Deskripsi data hasil belajar sebelum dan sesudah perlakuan

\begin{tabular}{ccccc}
\hline Nilai & \multicolumn{2}{c}{ Kelas Konvensional } & \multicolumn{2}{c}{ RME } \\
\cline { 2 - 5 } & Pretest & posttest & Pretest & posttest \\
\hline Rata-rata & 41,25 & 58,125 & 39,516 & 62,58 \\
Standar deviasi & 9,418 & 11,27 & 10,029 & 9,475 \\
Nilai maksimum ideal & 100 & 100 & 100 & 100 \\
Nilai minimum ideal & 0 & 0 & 0 & 0 \\
Nilai maksimum empiris & 60 & 80 & 60 & 80 \\
Nilai minimum empiris & 25 & 30 & 20 & 45 \\
\hline
\end{tabular}

Berdasarkan Tabel 4 dikrtahui bahwa rata-rata hasil belajar peserta didik di kelas konvensional lebih tinggi dibandingkan kelas RME, namun setelah perlakuan rata-rata hasil belajar peserta didik di kelas RME lebih tinggi dibandingkan kelas konvensional. Nilai tertinggi yang dicapai peserta didik di kedua kelas sama sama mencapai 80. Berdasarkan hasil pretest, nilai terendah yang dicapai dikelas kovensional lebih tinggi dibandingkan dengan kelas RME 
tetapi setelah perlakuan nilai terendah yang dicapai peserta didik di kelas RME lebih tinggi dibandingkan kelas konvensional.

Setelah data dideskripsikan, dilakukan uji hipotesis untuk menguji keefektifan pembelajaran menggunakan RME dan pembelajaran konvensional. Namun sebelumnya dilakukan uji asumsi normalitas dan homogenitas. Hasil uji normalitas sebelum dan sesudah perlakuan di kedua kelas disajikan pada Tabel 5.

Tabel 5

Hasil uji normalitas minat dan hasil belajar matematika peserta didik menggunakan SPSS

\begin{tabular}{|c|c|c|c|c|c|c|c|c|}
\hline \multirow[t]{3}{*}{ Variabel } & \multicolumn{4}{|c|}{ Kelas Konvensional } & \multicolumn{4}{|c|}{ Kelas RME } \\
\hline & \multicolumn{2}{|c|}{ Sebelum } & \multicolumn{2}{|c|}{ sesudah } & \multicolumn{2}{|c|}{ Sebelum } & \multicolumn{2}{|l|}{ sesudah } \\
\hline & $\begin{array}{c}\text { Asymp. } \\
\text { Sig }\end{array}$ & Ket. & $\begin{array}{c}\text { Asymp. } \\
\text { Sig }\end{array}$ & Ket. & $\begin{array}{c}\text { Asymp. } \\
\text { Sig }\end{array}$ & Ket. & $\begin{array}{c}\text { Asymp. } \\
\text { Sig }\end{array}$ & Ket. \\
\hline Minat belajar & 0,286 & normal & 0,243 & normal & 0,96 & normal & 0,79 & Normal \\
\hline Hasil belajar & 0,206 & normal & 0,36 & normal & 0,425 & normal & 0,77 & Normal \\
\hline
\end{tabular}

Dari Tabel 5 dapat diambil kesimpulan bahwa data minat belajar peserta didik sebelum dan sesudah perlakuan di kedua kelas berdistribusi normal. Hal ini ditunjukkan dengan nilai signifikansi masing-masing lebih besar dari 0,05. Hal yang sama juga terjadi pada data hasil belajar matematika peserta didik di kedua kelas. Nilai signifikansi data hasil belajar matematika sebelum dan sesudah perlakuan di kedua kelas lebih besar dari 0,05 yang artinya data berdistribusi normal.

Homogenitas varians dapat dilihat dari hasil Levene's Test menggunakan bantuan software SPSS. Hasil output SPSS yang menguji homogenitas variansi antara dua kelas pada masing-masing variabel dependen dapat dilihat pada Tabel 6.

Tabel 6

Hasil uji homogenitas minat dan hasil belajar matematika peserta didik menggunakan SPSS

\begin{tabular}{ccccc}
\hline Variabel & \multicolumn{2}{c}{ Sebelum } & \multicolumn{2}{c}{ Sesudah } \\
\cline { 2 - 5 } & Asymp. Sig & Ket & Asymp. Sig & Ket \\
\hline Minat belajar & 0,878 & homogen & 0,75 & homogen \\
Hasil belajar & 0,86 & homogen & 0,419 & homogen \\
\hline
\end{tabular}

Dari Tabel 6 dapat diambil kesimpulan bahwa homogenitas data minat dan hasil belajar belajar peserta didik sebelum dan sesudah perlakuan terpenuhi. Hal ini ditunjukkan dengan nilai signifikansi masing-masing lebih besar dari 0,05. Karena asumsi normalitas dan homogenitas terpenuhi, selanjutnya dilakukan uji hipotesis. Hasil uji hipotesis menggunakan uji paired sample t test disajikan pada Tabel 7.

Tabel 7

Hasil uji paired sample t test minat dan hasil belajar matematika

\begin{tabular}{ccccc}
\hline \multirow{2}{*}{ Variabel } & \multicolumn{4}{c}{ Kelas } \\
\cline { 2 - 5 } & \multicolumn{2}{c}{ Konvensional } & \multicolumn{2}{c}{ RME } \\
\cline { 2 - 5 } & Asymp. Sig & Ket & Asymp. Sig & Ket \\
\hline Minat belajar & 0,00 & H0 Ditolak & 0,00 & H0 Ditolak \\
Hasil belajar & 0,00 & H0 Ditolak & 0,00 & H0 Ditolak \\
\hline
\end{tabular}


Dari Tabel 7 dapat diambil kesimpulan bahwa pembelajaran menggunakan RME maupun pembelajaran konvensional efektif ditinjau dari minat belajar dan hasil belajar matematika. Hal ini dapat dilihat dari hasil uji paired sample $t$ test yang menunjukkan nilai signifikansi kurang dari 0,05. Penerapan RME dalam pembelajaran matematika merupakan salah satu cara dalam menarik minat belajar siswa dan meningkatkan hasil belajar siswa. Hal ini sejalan dengan penelitian Mulyani (2018) yang memperoleh hasil bahwa pembelajaran menggunakan RME dapat meningkatkan minat belajar siswa. Pembelajaran matematika dengan RME menggunakan masalah nyata (real) yang ditemui peserta didik dalam kehidupan sehari-hari. Dengan adanya masalah tersebut, peserta didik akan memahami bahwa matematika sebenarnya dekat dengan kehidupan sehari-hari. Penggunaan masalah nyata dalam pembelajaran matematika juga membuat peserta didik menyadari akan manfaat matematika dalam kehidupan sehari-hari sehingga pembelajaran akan lebih bermakna. Pembelajaran yang bermakna ini akan menarik minat siswa dalam belajar matematika. Hal ini ditegaskan oleh Hamalik (2017) bahwa minat belajar akan muncul jika peserta didik merasa bahwa pembelajaran yang dilakukan bermakna. Penggunaan pendekatan RME dalam penelitian ini juga menggunakan benda-benda konkret dalam pembelajaran pecahan. Benda konkret yang digunakan adalah buah apel dan semangka. Benda-benda konkret tersebut digunakan untuk membantu peserta didik memahami bilangan pecahan. Prinsip yang digunakan dalam RME ini adalah menggunakan benda konkret untuk mengenalkan bilangan pecahan yang bersifat abstrak. Penggunaan benda konkret ini akan menarik minat peserta didik untuk belajar matematika yang bersifat abstrak. Hal ini seperti yang diungkapkan oleh Azmidar, Darhim \& Dahlan (2017) bahwa untuk meningkatkan minat peserta didik dalam pembelajaran matematika, guru dapat menggunakan pembelajaran yang dimulai dengan benda konkret kemudian gambar baru dikenalkan ke materi yang abstrak.

Pembelajaran menggunakan RME efektif ditinjau dari hasil belajar matematika juga sejalan dengan penelitian Zainil (2017). Dalam penelitian Zainil, pembelajaran dengan RME dapat meningkatkan aktivitas guru dan peserta didik yang berdampak pada meningkatnya hasil belajar peserta didik di semua domain, yaitu afektif, kognitif, dan psikomotor. Dalam pembelajaran menggunakan RME, peserta didik dilatih mengkonstruk penegetahuannya melalui benda-benda konkrit. Selain itu, peserta didik dilatih untuk menyelesaikan masalah dengan caranya sendiri (Hadi, 2018). Hal inilah yang diduga dapat meningkatkan hasil belajar peserta didik.

Setelah diketahui bahwa kedua pendekatan pembelajaran efektif ditinjau dari minat dan hasil belajar matematika, selanjutnya akan dilihat pendekatan mana yang lebih efektif ditinjau dari masing-masing variabel. Uji yang digunakan adalah uji independent sample t test. Hasil uji independent sample t-test disajikan pada Tabel 8.

Tabel 8

Hasil uji independent sample t test minat dan hasil belajar matematika

\begin{tabular}{ccc}
\hline Variabel & Asymp. Sig & Keterangan \\
\hline Minat belajar & 0,00 & H0 Ditolak \\
Hasil belajar & 0,095 & H0 Diterima \\
\hline
\end{tabular}

Hasil uji independent sample $t$ test pada Tabel 8 menunjukkan bahwa pembelajaran menggunakan RME lebih efektif ditinjau dari pembelajaran konvensional. Pembelajaran RME lebih efektif dibandingkan dengan konvenional ditinjau dari minat belajar dalam penelitian ini disebabkan karena guru memberikan benda-benda konkret agar peserta didik dapat menemukan 
sendiri konsep pecahan. Penggunaan benda-benda nyata tersebut juga berdampak pada perhatian peserta didik dalam proses pembelajaran. Peserta didik menjadi lebih memperhatikan guru dalam memperagakan konsep pecahan dengan benda konkret kemudian peserta didik mencobanya secara berkelompok.

Hasil penelitian ini sedikit berbeda dengan hasil penelitian Karaca \& Ozkaya (2017). Hasil penelitian Karaca \& Ozkaya menunjukkan bahwa pembelajaran RME lebih efektif ditinjau dari minat dan hasil belajar peserta didik. Meskipun pembelajaran dengan RME efektif ditinjau dari hasil belajar matematika serta rata-rata hasil posttest peserta didik lebih tinggi dari kelas konvensional namun hasil uji perbandingan rata-rata menggunakan independent sample t test menunjukkan perbedaan rata-rata di kedua kelas tidak signifikan. Hal ini kemungkinan disebabkan pembelajaran RME belum terbiasa digunakan dalam pembelajaran, dan waktu penelitian yang terbatas menyebabkan peserta didik belum terbiasa mengkonstruk pengetahuannya sendiri sehingga konsep yang dipahami peserta didik belum maksimal.

\section{Kesimpulan}

Berdasarkan hasil penelitian dan pembahasan dapat disimpulkan bahwa pembelajaran matematika menggunakan RME efektif ditinjau dari minat dan hasil belajar kognitif peserta didik sekolah dasar. Selain itu pembelajaran menggunakan RME lebih efektif dibandingkan dengan pembelajaran konvensional ditinjau dari minat belajar peserta didik namun tidak lebih efektif ditinjau dari hasil belajar matematika. Berdasarkan hasil penelitian ini, diharapkan guru membiasakan menggunakan masalah kontekstual atau benda-benda konkret dalam pembelajaran. Selain itu, peserta didik diharapkan dilatih untuk mengkonstruk pengetahuaannya sendiri. Sehingga peserta didik dapat memahami konsep materi matematika lebih maksimal.

\section{Daftar Pustaka}

Azmidar, A., Darhim, D. \& Dahlan, J.A. (2017). Enhancing Students' Interest through Mathematics Learning. IOP Conf. Series: Journal of Physics: Conf. Series 895 (2017) 012072.

Bray, A. \& Tangney, B. (2015). Enhancing student engagement through the affordances of mobile technology: A 21st century learning perspective on realistic mathematics education. Mathematics Education Research Journal, 28 (1).

Elliot, S N., et al. (2000). Educational psychology: effective teaching, effective learning. Boston, MA: The McGraw-Hill Companies, Inc.

Clements, D. H., \& Sarama, J. (2013). Rethinking early mathematics: What is research based curriculum for young children? In L. D. English \& J. T. Mulligan (Eds.), Reconceptualizing early mathematics learning, 121-147.

Heuvel, A.V. D., \& Panhuizen. (2003). The didactical use of models in realistic mathematics education: an example from a longitudinal trajectory on percentage. Educational Studies in Mathematics, 54, 9-35.

Hadi, S. (2018). Pendidikan Matematika Realistik teori, pengembangan, dan Implementasinya. Depok: Rajawali pers.

Hamalik, O. (2017). Proses Belajar Mengajar. Jakarta: Bumi Aksara.

Harackiewicsz, J.M., Smith, J. L. \& Priniski, S. J. (2016). Interest matters: the importance of promoting interest in education. Policy Insight Behav Brain Sci, 3 (2), 220-227.

Hudojo, H. (2005). Pengembangan Kurikulum dan Pembelajaran Matematika. Malang: UM Press.

Karaca, Y. \& Ozkaya, A. (2017). The effects of realistic mathematics education on students' math self reports in fifth grades mathematics course. International Journal of Curriculum and Instruction, 9 (1), 81-103.

Kurino, Y. D. (2019). Model realistic mathematic education pada pelajaran matematika di sekolah dasar. Jurnal cakrawala pendas, 5 (2), 184-187. 
Laurens, T., dkk. (2018). How does realistic mathematics (RME) improve students' mathematics cognitive achievement?. Eurasia Journal of Mathematics, Science and Technology Education 14 (2) 569-578.

Mullis, I.V.S., dkk. (2015). TIMSS 2015 Assessment Frameworks and Specification. Chestnut Hill MA: TIMSS \& PIRLS International Study Center, Boston Collage

Mulyani, S. (2018). Penerapan Pembelajaran Matematika Realistik (PMR) untuk Meningkatkan Minat dan Hasil Belajar Siswa pada materi Aritmatika Sosial Kelas VII H Semester I SMPN I Gubug Tahun Pelajaran 2017/2018. Jurnal Matematika dan Pendidikan Matematika, 84-91.

NCTM (2000). Principles and standards for school mathematics. Reston, VA: NCTM.

Slameto. 2003. Belajar dan faktor-faktor yang Mempengaruhinya. Jakarta: PT. Rineka Cipta

Tella, A. 2007. The impact of motivation on student's academic achievement and learning outcomes in mathematics among secondary school students in Nigeria. Eurasia Journal of Mathematics, Science \& Technology Education, 3(2), 149-156.

Zainil, M. (2017). Proceeding in the 9th International Conference for Science Educators and Teacher, 172-178. Atlantis Press. 